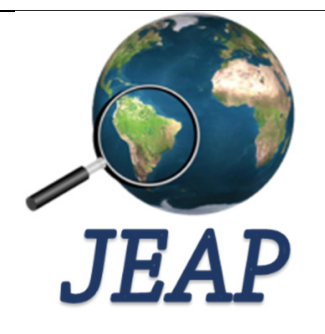

ISSN: 2525-815X

\section{Journal of Environmental} Analysis and Progress

\author{
Journal homepage: www.ufrpe.br/jeap
}

http://dx.doi.org/10.24221/jeap.1.1.2016.978.1-12
ISSN:2525-815X

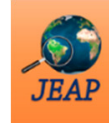

Journal of Environmental Analysis and Progress

\title{
Monitoring canopy and air temperature of dominant vegetation in tropical semi-arid using bioclimatic model
}

\author{
Josiclêda Domiciano Galvíncio ${ }^{\mathrm{a}}$, Rejane Magalhães de Mendonça Pimentel ${ }^{\mathrm{b}}$ \\ ${ }^{a}$ Universidade Federal de Pernambuco-UFPE, Departmento de Ciências Geográficas. Av. Professor Morais Rego, s/n, \\ Cidade Universitária, Recife-PE, Brasil. CEP: 50670-901. E-mail: josicleda@ hotmail.com. \\ b Universidade Federal Rural de Pernambuco-UFRPE, Departmento de Biologia/Área de Botânica. Rua Manoel de \\ Medeiros, S/N, Dois Irmãos, Recife-PE, Brasil. CEP: 52171-900. E-mail: rmmpimentel@ hotmail.com.
}

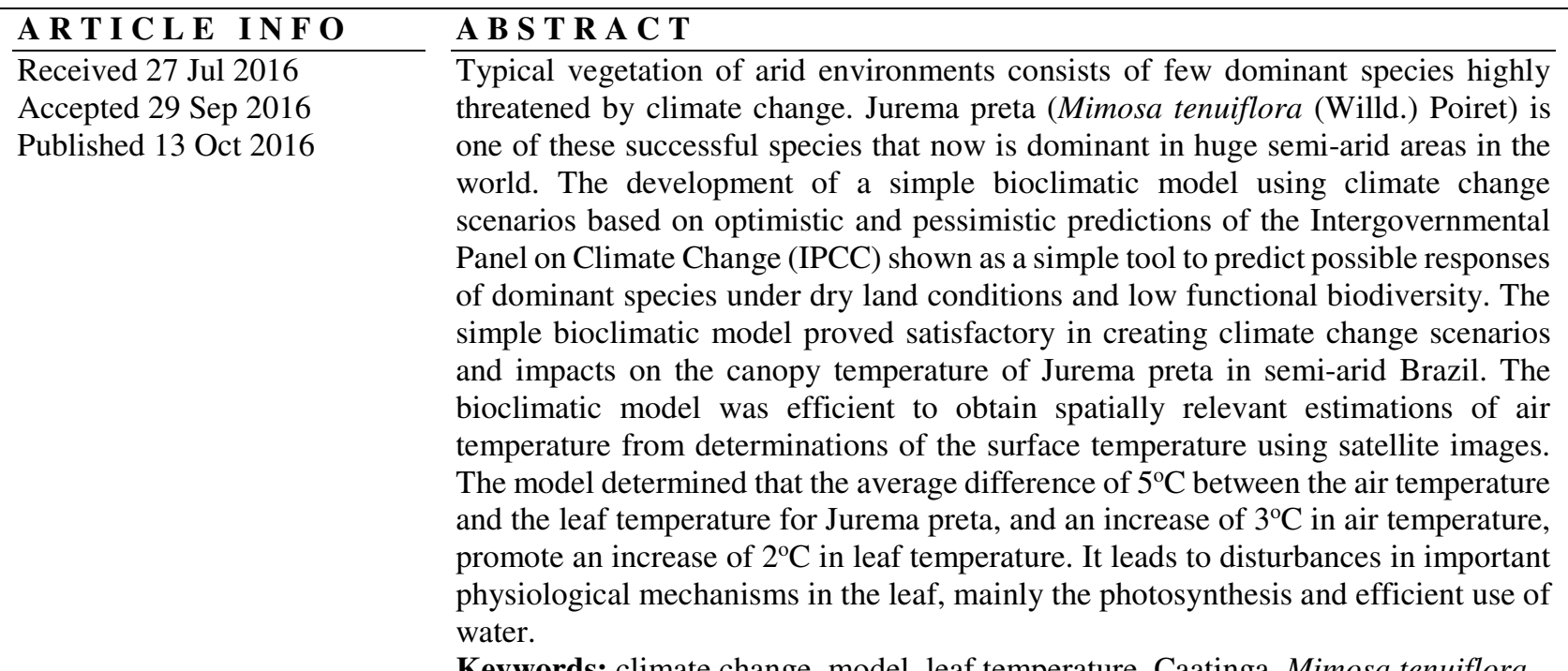

\section{Introduction}

Aridity is the major environmental condition that influences the surveillance of plants, especially in consequence of water scarcity. Some successful species became dominant in the major arid regions of the world. Driest regions in the world are characterized by species capable of surviving and completing its life cycle under a scarcity of water, like in Asia, Americas, United States, Chile and Argentina (Burkart, 1976). It is particularly true in tropical regions with the lowest rainfall during the year, like in Africa and South America. Perennial plants contribute to influence the climate, especially the air temperature, improving the predictability of the climate conditions through the temperature alleviation.

Climate models indicate increased irregularities and decreased rainfall in semi-arid regions in the world (Marengo, 2007). If these future scenarios occur, some plant species may disappear. Many researchers have been interested in developing studies on ways to minimize the impact of climate changes on natural resources (Marengo, 2007; Da Silva et al., 2009; Santos et al., 2009; Galvíncio et al., 2010; Galvincio \& Moura, 2010).

The leaf temperature is one fundamental feature to understanding many performances in functional plant ecology. Its significance in plants' water relations was recognized early in the 20th century (Raschke, 1960). Based on research on the heat transfer between plants and the environment and on plants' water management, the canopy temperature has been used as an indicator in agrihorticulture since the 1960s (Fuchs \& Tanner, 1966; Jackson et al., 1977; Fuchs, 1990; Jones, 
2004). Other applications, such as climate modeling of the earth's surface (Dai et al., 2004), assess how increases in the surface temperatures could be caused by global warming (Zaitchik et al., 2006).

The use of aircraft and satellites can determine the temperature and the deforestation from vast areas of land in a short time. The current models need adjustment to the new technologies, especially to explain the environmental variations in the canopy and among the species. As opposed to the average temperature obtained by satellites, the distribution of temperature (using a scale and diurnal variations) is determinant to the flow of heat and gasses between surface and atmosphere. In temperate and tropical forests, in particular for trees with large leaves, the canopy temperatures can substantially differ among species (Grace, 1977).

The energy equilibrium in a leaf of a dominant species established in hard adverse climatic conditions, especially high temperatures, informs about the grade of the influence of this vegetation coverture in extensive areas. Due to evapotranspiration, the temperature in the leaves may be a few degrees below the air temperature (Pillar, 1995); it regulates the transpiration and photosynthesis of the leaf (Larcher, 2003). Stomatal conductance is a powerful physiological mechanism that allows plants to control vascular perspiration. Stomatal resistance is a response to several environmental factors that affect its behavior simultaneously. In illuminated leaves, it depends on the air temperature, the vapor pressure deficit, the concentration of $\mathrm{CO}_{2}$ and the water potential in the soil (Pimentel \& Perez, 2000). These authors also point out that an increase of solar radiation, and consequent higher air temperature, causes increased stomatal resistance by reducing the potential for soil water. Several studies claim that light and water are the two environmental factors with the greatest effects on the behavior of stomata (Silva et al., 1998), and influence the leaf temperature. As a consequence, this study aimed to develop a bioclimatic model to monitoring the canopy surface temperature and air temperature in areas covered with dominant semiarid vegetation in tropics.

\section{Material and Methods}

The study considered extensive areas covered by savanna vegetation, popularly named caatinga in Brazil, with a predominance of individuals of Mimosa tenuiflora (Willd.) Poiret, a shrub species, in the municipally of São José do Sabugi, at Paraíba State, Brazil (Figure 1). This area comprises $215.4 \mathrm{~km}^{2}$ with an average annual precipitation of $500 \mathrm{~mm}$ (Galvíncio et al., 2010), concentrated from January to April and temperatures around $28^{\circ} \mathrm{C}$ (Moura et al., 2012), always lower than $40^{\circ} \mathrm{C}$ (Prado, 2003).
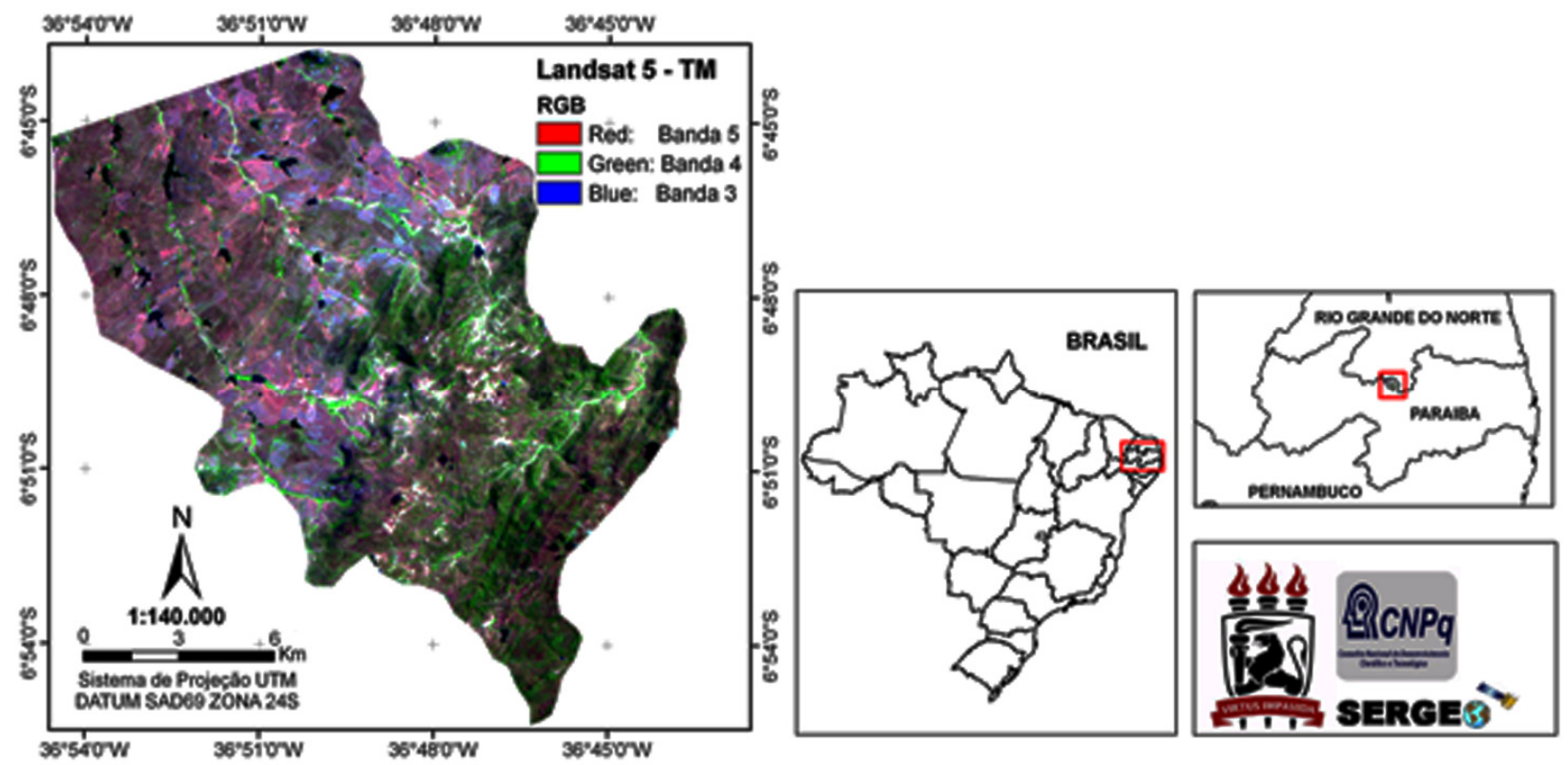

Figure 1. Spatial localization of the municipally of São José do Sabugi, in Paraíba, Brazil.

On January 13, 2009, five variables: leaf surface temperature of Jurema preta, air humidity, air temperature, soil surface temperature and soil temperature at $10 \mathrm{~cm}$ depth were obtained at five coordinates: a) site 01 - 738574 x, 9246370 y; b) site 02 - 738549 x, 9246394 y; c) site $03-736409$ $\mathrm{x}, 9245108 \mathrm{y}$; d) site 04 - $742458 \mathrm{x}, 9243340 \mathrm{y}$; e) site 05 - $741448 \mathrm{x}, 9240072 \mathrm{y}$, with six sampling 
per coordinate. All measurements in the field were made on a clear sky day.

The temperature and humidity were measured with a portable digital thermohygrometer (Model THGR122NX, Oregon Scientific, USA) (Figure 3). The surface temperatures of the soil and leaves were measured with a digital infrared thermometer laser (Model 7662, Incoterm, China). The soil temperature was measured with a thermometer from Incoterm.
Temperature measurements of the ground surface were obtained with sensors located at a distance of $1 \mathrm{~m}$ from the surface with a zenith angle of $90^{\circ}$. The temperatures of air and leaf surface were measured with sensors at $1.5 \mathrm{~m}$ height and angle of $180^{\circ}$. A digital camera with the RICOH 500SE GPS was used with infrared sensors for collecting georeferenced images of plants and canopy. Measures from the surface temperature of canopy and air were correlated.
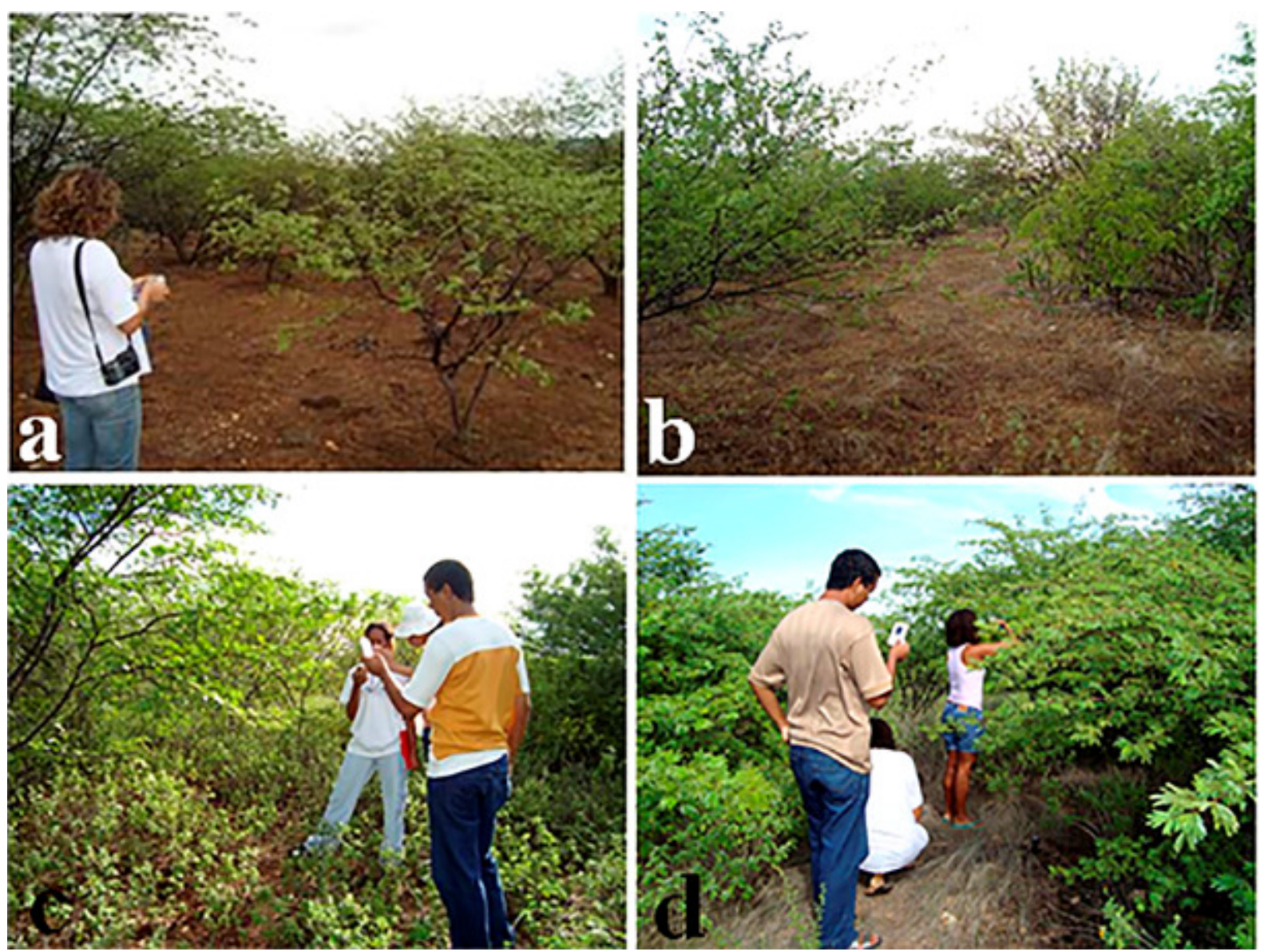

Figure 2. Vegetation coverage with Jurema preta (Mimosa tenuiflora (Willd) Poiret) in São José do SabugiPB, in the semi-arid northeastern of Brazil. Sampling sites at five coordinates: a) site 01 - 738574 x, y 9246370 ; b) site 02 - 738549 x, y 9246394; c) site 03 - 736409 x, y 9245108; d) site 04 - x 742 458, y 9243340; e) site 05 - x 741448 , y 9240072.

Data from the meteorological station came from the Oregon weather station WMR-9x8, in the Datalogger WMR918/928/968, using the software WMRDL Monitor and sent to Excel. This study used data of the air temperature from January 13, 2009. The sensors to detect the temperature and humidity of the weather stations were installed at $1.5 \mathrm{~m}$ height. Measures from the meteorological station were correlated with field data of five replicates during one day in the times of 7.5, 8.0, 11.5, 15.5 and 16 hours, on January 13, 2009.

An image from Landsat 5 - TM on January 13,2009 , from orbit 215 and point 65 , was used to estimate the surface temperature of the canopy and after to establish a correlation with similar data collected in the field.

The image processing used the equations published previously by many authors (Markham \& Baker, 1987; Huete, 1988; Huete \& Warrick, 1990; Bastiaanssen, 1995; Bastiaanssen, 2000; Accioly et al., 2002; Allen et al., 2002; Boegh et al., 2002; Silva et al., 2005; Galvíncio et al., 2010), including the measurements of the estimation of the temperature surface.

The emissivity obtained in the previous step was used to determine the surface temperature (Ts) applied in the spectral radiance of the thermal band 
for $\mathrm{L}_{\lambda, 6}$ and $\varepsilon_{\mathrm{NB}}$. Thus, the surface temperature (K) data were obtained from the following expression:

$$
\mathrm{T}_{\mathrm{s}}=\mathrm{k}_{2} / 1 \mathrm{n} .\left(\varepsilon_{\mathrm{NB}} \cdot \mathrm{K}_{1} / \mathrm{L}_{\lambda, 6}+1\right),
$$

where $\mathrm{K}_{1}=607.76 \mathrm{Wm}^{-2} \mathrm{sr}^{-1} \mu \mathrm{m}^{-1}$ and $\mathrm{K}_{2}=1260.56$ $\mathrm{K}$ were the calibration constants for the thermal band of Landsat 5 - TM (Allen et al., 2002; Silva et al., 2005; Galvíncio et al., 2010).

Descriptive statistics and Pearson correlation analysis were applied to the variable's air temperature, air humidity, soil and leaf surface temperature and soil temperature at $10 \mathrm{~cm}$ depth.

The mathematical formulation of the model was a result of the statistical method of multiple linear regression. The evaluation criteria of the model were the linear correlation among observed values and those estimated by the model, percentage error, and absolute error.

After the development, calibration and verification of the model, simple bioclimatic scenarios of climate change impacts on the energy balance of the canopy of Jurema preta were produced. The scenarios related to the changes in temperature from canopy and leaf of Jurema preta were based on the most optimistic and pessimistic scenarios presented by IPCC (2007). These included the most optimistic scenario, which has an increase in average air temperature of $1^{\circ} \mathrm{C}$, and the worst-case scenario an increase of $3^{\circ} \mathrm{C}$.

\section{Results}

The soil moisture at $0-10 \mathrm{~cm}$ was $10 \%$ on average of water content, considered as a soil with low field capacity, meaning that the trees were probably under a maximum transpiration rate.

Figure 3 shows the ratio of daily variations in the average temperatures of the leaf surface, soil surface and air on January 13, 2009. The temperature of the surface of the soil tends to be near the air temperature at the end of the day, and the temperatures of the leaf surface and air showed similar behavior. It was confirmed by the strong relationship between different temperatures; the correlation between the leaf surface temperature of Jurema preta and air temperature (to a level of significance of 0.005 ) was $92 \%$.

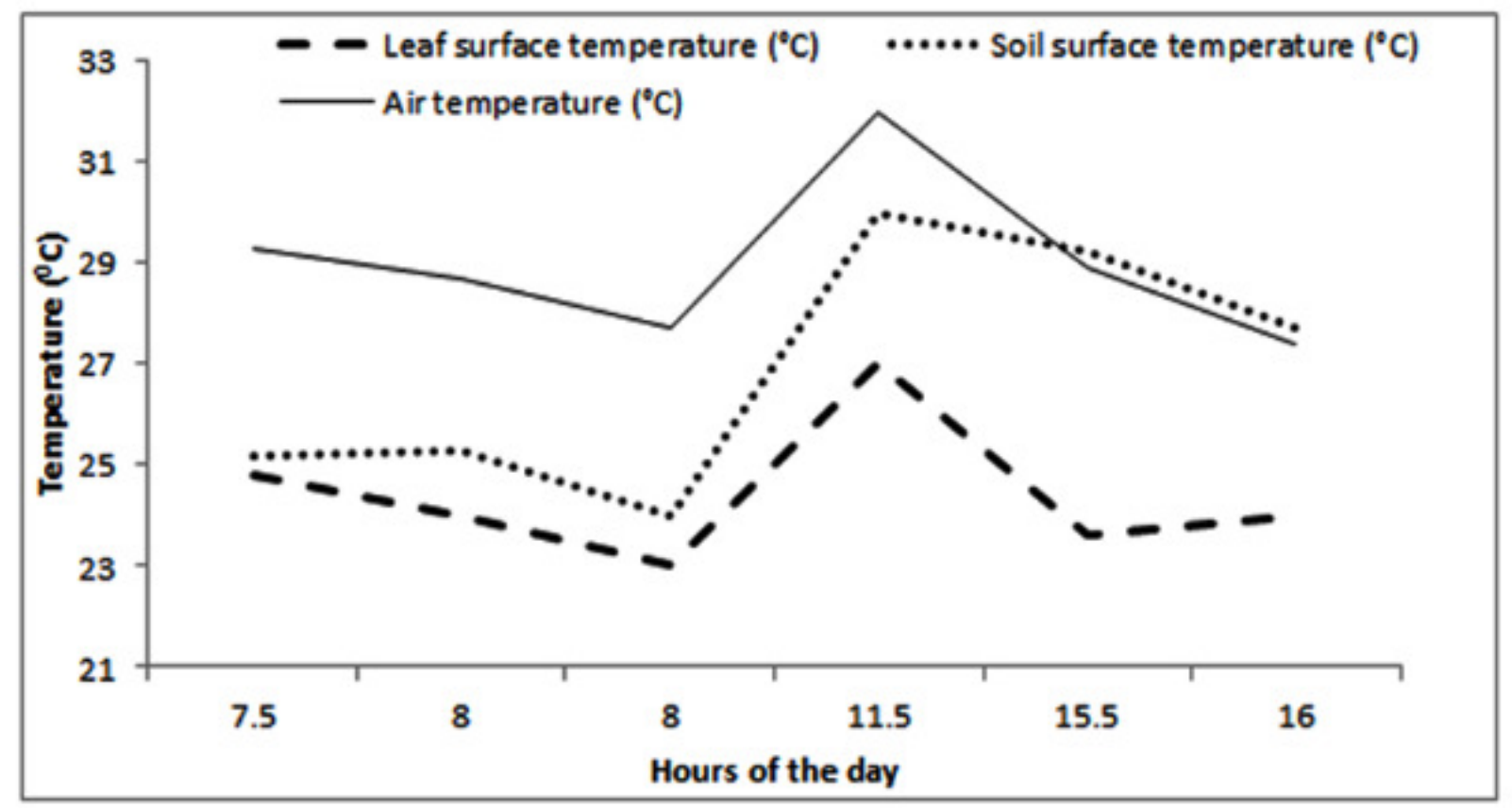

Figure 3. Relationship of daily variations in the average temperatures of the leaf surface, soil surface and air on January 13, 2009.

The daily air temperatures (Figure 4) showed an opposite behavior when compared with the daily relative humidity in the air (Figure 5), and the average daily winds speed oscillated during all day (Figure 6).

On a simulation day, at 09:40 (time according to the imaging satellite Landsat 5 - TM), the weather station, shown in Figure 7A with a black spot, recorded an air temperature of around $28^{\circ} \mathrm{C}$ while the satellite-based estimation of the surface temperature was $27^{\circ} \mathrm{C}$ (Figure $7 \mathrm{~A}$ ). The validation of the results of temperature estimated with satellite images can be found in Galvíncio et al. (2009). In the black spot, where the surface temperature was $28^{\circ} \mathrm{C}$, the SAVI was, approximately, 0.14, as shown in Figure 7B. 
Journal of Environmental Analysis and Progress V. 01 N. 01 (2016) 1-12

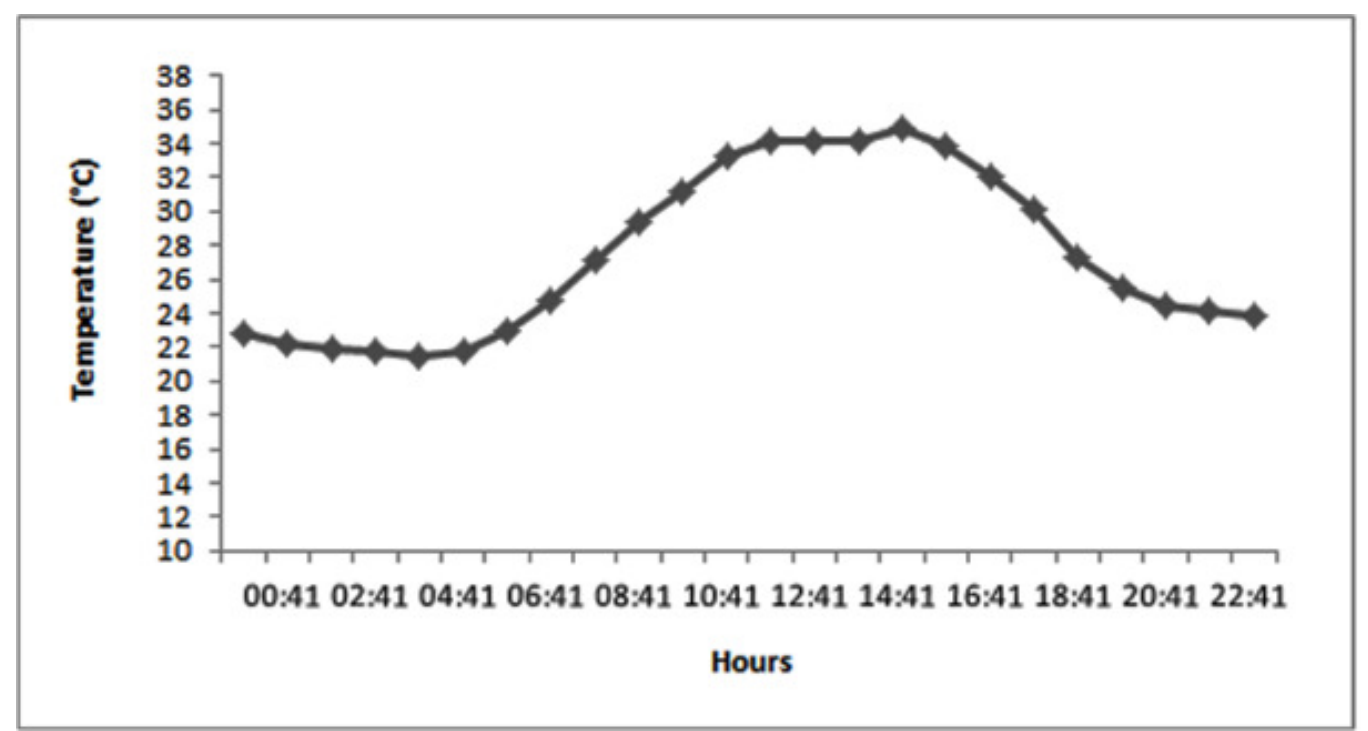

Figure 4. Air temperatures in the municipality of São José do Sabugi-PB on January 13, 2009.

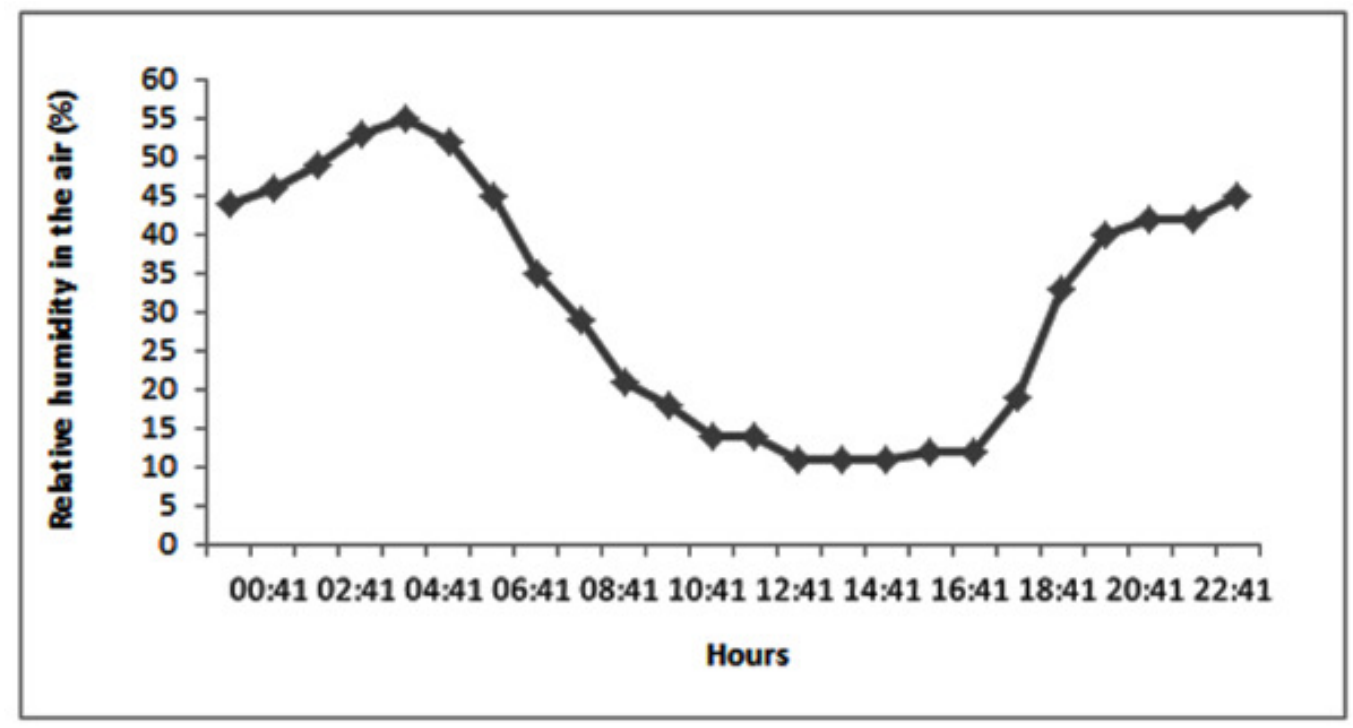

Figure 5. Relative humidity in the air in the municipality of São José do Sabugi-PB on January 13, 2009.

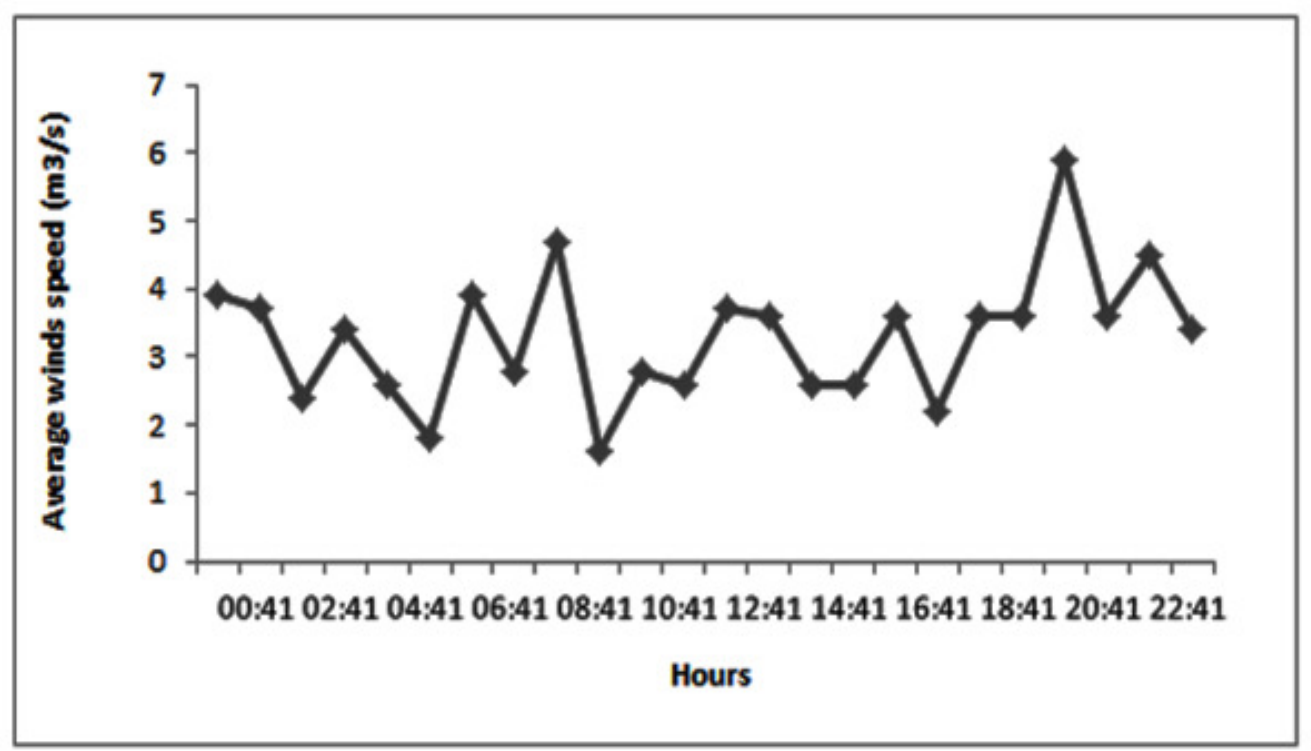

Figure 6. Average wind speed in the municipality of São José do Sabugi-PB on January 13, 2009. 
The relationship between the vegetation cover (SAVI) and surface temperature was negative (Figure 7), indicating that higher SAVI values correspond to low temperature values.

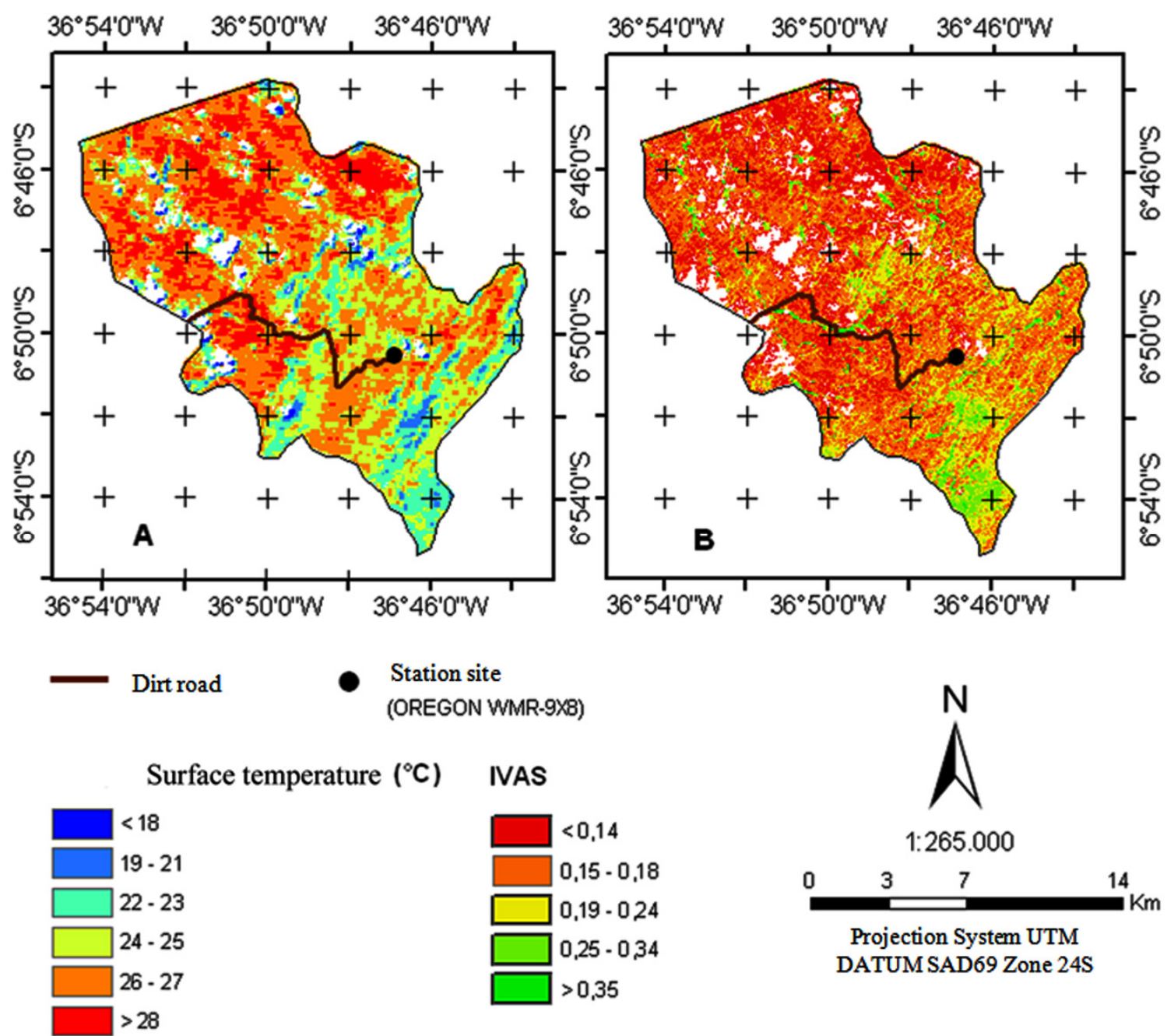

Figure 7. Surface temperature (A) and SAVI (B) in the municipality of São José do Sabugi-PB on January 13, 2009.

According to the observed in the field, this area corresponds to bare soil and grassland. It is possible to see the great visual relationship between the density of vegetation cover and the surface temperature of the canopy. The surface of the soil temperature oscillated between $26^{\circ} \mathrm{C}$ and $28^{\circ} \mathrm{C}$; the difference of two degrees was sufficient to produce differences in the landscape.

The regression equation $\mathrm{Y}=0.787 \mathrm{X}+1.571$ was obtained, with $\mathrm{R}^{2}=0.846$, i.e., $\mathrm{Tf}=0.787 \mathrm{Ta}$ +1.571 , where $\mathrm{Tf}$ is the leaf temperature, Ta is the air temperature, and $\mathrm{Ta}=(\mathrm{Tf}-1,571) / 0.787$.

The values estimated by the model showed a significant relationship with the measured values (Figure 8). Most samples showed regression values below 0.5 (Figure 9).

It is still important to note that the difference between the leaf temperature of Jurema preta and the air temperature was around $5^{\circ} \mathrm{C}$ lower in the leaf.

The bioclimatic model here purposed was capable of estimating the surface temperature of the leaf by using the values of air temperature and vice versa. The air temperature determined by the model was $29^{\circ} \mathrm{C}$ and the value found in the weather station was around $28^{\circ} \mathrm{C}$. Thus, the estimation of this bioclimatic model represents $96 \%$ of the observed value or a relative error of 0.04 and an absolute error of $1^{\circ} \mathrm{C}$.

An increase in air temperature of $3^{\circ} \mathrm{C}$ would increase the leaf temperature by $2^{\circ} \mathrm{C}$ for individuals of Jurema preta growing in the semi-arid conditions, and a $1^{\circ} \mathrm{C}$ increase in air temperature would cause a $0.8^{\circ} \mathrm{C}$ rising in the leaf temperature of this species. 


\section{Leaf surface temperature $\left({ }^{\circ} \mathrm{C}\right)$}

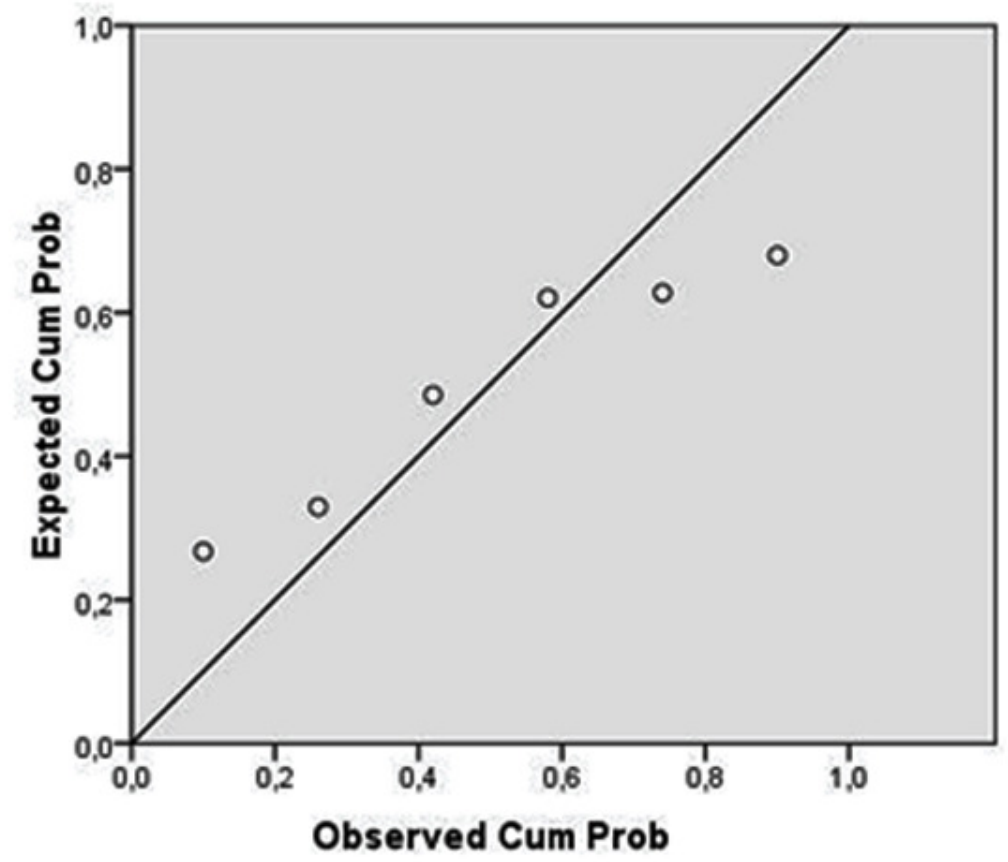

Figure 8 . The relationship between the observed leaf temperature and that estimated by the model.

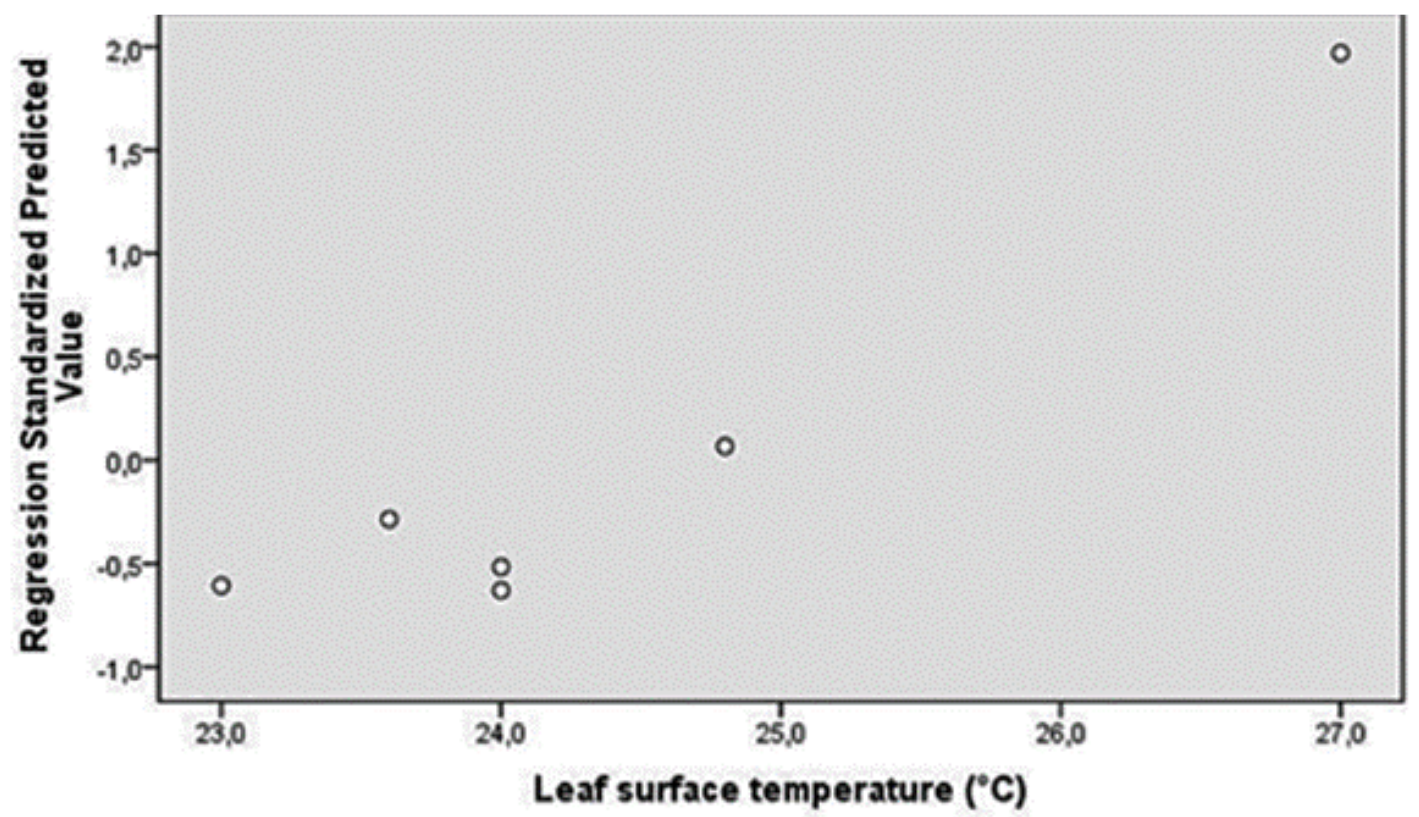

Figure 9. The relationship between the estimated values of the regression and the surface temperature of the leaf.

\section{Discussion}

Species that can survive in soils under field capacity are considered resistant to severe drought. In general, these species have deep root system capable of absorbing water in the water table.

The opposite conditions between the daily air temperatures oscillation and the daily relative humidity in the air, and the daily average winds speed indicate that, apparently, the winds speed not influenced the water content in the atmosphere, and that the air humidity is related to the air temperature.

Leuzinger \& Korner (2007) emphasized the importance of these studies under tropical 
conditions. When the difference between the leaf temperature and air temperature is not so high, here it was around $4^{\circ} \mathrm{C}$, is expected minimum effects over the physiological mechanisms of the leaf in a plant established under extreme climatic conditions, as in a semi-arid region. It can explain the dominance of this species in that ecosystem.

It was possible to note that this difference of only two degrees in the soil temperature was a result of the coverture of the ground, influenced by the density of individuals of Jurema preta favoring the growth of other small species in the surroundings.

The soil temperature influences the adjacent area nearest the surface of the soil predominantly without altering the air and leaf temperatures.

The evaluating of the relationships between the air and soil temperatures, and between air and leaf temperatures showed best results when using only data from leaf temperature, without including the soil temperature.

Considering the lower temperature in the leaf, around $5^{\circ} \mathrm{C}$, in contrast with the air temperature, Pillar (1995) stated that this difference of temperature could reach until $20^{\circ} \mathrm{C}$ in some plants, and this reduction occurs through the leaf transpiration, stomatal and cuticular. The volume of intercellular spaces, a greater thickness of mesophyll, a higher number of parenchyma cells, reduction of leaf area, and density of stomata, all contribute to maintaining the temperature lower (Wilson \& Cooper, 1969; Godoy et al., 2011). As transpiration is a mechanism that permits the water loss by the plant, the apparent lower difference of temperature found in Jurema preta, only $5^{\circ} \mathrm{C}$, can be a result of a strategy to reduce the water loss through transpiration. It is shown as an excellent mechanism for plants that must survive in semiarid environments as in Caatinga (savanna), where high temperature represents a limitation to its surveillance. Leuzinger \& Korner (2007) highlighted the importance of the restriction of the temperature differences between plant and air for the achievement of several physiological mechanisms, as photosynthesis, respiration, and transpiration. It is believed that this model can be applied to other species of this biome or similar, mainly those that show similar characters to Jurema preta.

Investigations of water relations, leaf anatomy traits, and air and leaf temperatures indicate that exist a relationship among them; thicker leaves were observed in plants established in environments with highest temperatures (Chabot \& Chabot, 1977).

Pillar (1995) stated that the transpiration mechanism maintains the leaf surface temperature with a difference of until $20^{\circ} \mathrm{C}$ lower about the air temperature. The opening of the stomata regulates the flow of air between the internal leaf structure and the atmosphere, thereby controlling the water loss. The leaf boundary temperature influence and modifies the relationship among stomatal and cuticular transpiration and higher air temperatures, stimulating the cuticle transpiration after the stomatal closure (Pillar, 1995).

The high efficiency obtained in the bioclimatic model corroborates the value found by Gonçalves et al. (2002, unpubl. data) for a region with savanna vegetation in South Africa. It is, therefore, possible to obtain spatially relevant estimations of air temperature from determinations of the surface temperature using satellite images.

Galvíncio et al. (2010) analyzed the relationships between air and soil temperature and chlorophyll a and $\mathrm{b}$ for Jurema preta, and stated that when, both, the air and soil temperature increase, chlorophyll a level decrease and chlorophyll b level increase. Although, Klar (1984) reported that the air temperature directly affects the plant growth. Haskell et al. (2012) stated that the effects of the soil temperature on plant growth factors influenced physical, chemical and biological aspects, with direct interference on the processes of organic matter decomposition, nutrient, and water absorption and translocation into the plant. In general, the daily trend of air temperature in the canopy depends on the supply of solar radiation. The layer of leaves where the radiation is intercepted acts as a filter influencing the rate of long-wave radiation loss, the total absorbed energy used for evaporation of water from the soil, the plant transpiration intensity and the turbulent transport of heat in the canopy (Broadbent, 1950). The strata of the canopy that are subject to different and stronger thermal influences can have a greater acceleration of senescence in leaves exposed to higher temperatures (Jochum et al., 2007).

\section{Conclusion}

The Jurema preta presents morpho-structural features similar to other dominant species in the Caatinga that are dominant in other areas of the world. The model showed high correlations between leaf temperature and air; the simple and preliminary bioclimatic model showed efficiency for future applications in the regions vegetated with other dominant species, thus contributing to a more efficient monitoring of vegetation under arid environments.

Considering the scenarios projected by this simple bioclimatic model, the greater increase in air temperature and the higher proportion of the leaf temperature, all will act as an inhibitor of 
photosynthesis, respiration, and transpiration mechanisms. In the case of occurrence of the IPCC's most optimistic projection, these effects on leaf temperature and its consequences are already critical enough to generate the inhibitions described. New models of scenarios are being developed using a greater amount of weather data and biotic factors, using a larger number of dominant species in tropical arid environmental conditions.

\section{Acknowledgements}

Authors are thankful to the Productivity

Grant from the Conselho Nacional de Desenvolvimento Científico e Tecnológico (CNPq) Brazil to the authors Galvíncio, J.D. and Pimentel, R.M.M.

\section{References}

ACCIOLY, L. J.; PACHECO, A.; COSTA, T. C. C.; LOPES, O. F.; OLIVEIRA, A. J. 2002. Relações empíricas entre a estrutura da vegetação e dados do sensor TM/Landsat. Rev. Bras. de Eng. Agr. e Amb., v.6, p.492-498.

ALLEN, R. G.; TASUMI, M.; TREZZA, R. 2002. SEBAL (Surface Energy Balance Algorithms for Land). Advance Training and Users Manual Idaho Implementation, version 1.0.

ANSARI, A. Q.; LOOMIS, W. E. 1959. Leaf temperatures. Am. J. Bot., v.46, p.713-717.

BARNEBY, C. R. 1991. Sensitivae Censitae. A description of the genus Mimosa L. (Mimosaceae) in the New World. New York Botanical Garden, v.65, p.1-835.

BASTIAANSSEN, W. G. M. 1995. Regionalization of surface flux densities and moisture indicators in composite terrain. A remote sensing approach under clear skies in Mediterranean climates. PhD Thesis. Agricultural University of Wageningen. Netherlands.

BASTIAANSSEN, W. G. M. 2000. SEBAL Based sensible and latent heat fluxes in the irrigated Gediz Basin, Turkey. J Hydrol., v.229, p.87-100.

BEGG, J. E.; TURNER, N. C. 1976. Crop water deficits. Adv. Agron., v.28, p.161-207.

BOEGH, E.; SOEGAARD, H.; THOMSEN, A. 2002. Evaluating evapotranspiration rates and surface conditions using Landsat TM to estimate atmospheric resistance and surface resistance. Remote Sens. Environ., v.79, p.329-343.

BROADBENT, L. 1950. The microclimate of the potato crop. Q. J. Roy. Meteor. Soc., v.76, p.439454.

BURKART, A. A. 1976. Monograph of the genus Prosopis (Leguminosae subfam. Mimosoideae). Journal of the Arnold Arboretum, v.57, p.450-525.

CHABOT, B. F.; CHABOT, J. F. 1977. Effects of light and temperature on leaf anatomy and photosynthesis in Fragaria vesca. Oecologia, v.26, p.363-377.

DA SILVA, D. F.; GALVÍNCIO, D. G.; SILVA, D. F.; ALMEIDA, H. R. R. de C. 2009. Análise Espaço-Temporal de Parâmetros de Qualidade de água no alto São Francisco e sua relação com intervenções antrópicas. Revista de Engenharia Ambiental: Unipinhal, v.6, p.492-518.

DAI, Y. J.; DICKINSON, R. E.; WANG, Y. P. 2004. A two-big-leaf model for canopy temperature, photosynthesis, and stomatal conductance. J. Climate, v.17, p.2281-2299.

EHRLER, W. L.; VAN BAVEL, C. H. M. 1973. Cotton leaf temperatures as related to soil water depletion and meteorological factors. Agron. J., v.65, p.404-409.

FLEMING, P. M.; ANTONINO, A. C. D.; PIMENTEL, R. M. DE M.; LIRA, C. A. B. DE O.; ALVES, G. D.; CABRAL, J. J. DA S. P. 2003. Transpiração em Plantas de Algaroba (Prosopis juliflora (Sw.) DC.) Cultivadas no Semi-Árido Nordestino. Revista Brasileira de Recursos Hídricos, v.8, p.25-30.

FUCHS, M. 1990. Infrared measurement of canopy temperature and detection of plant water-stress. Theor. Appl. Climatol., v.42, p.253-261.

FUCHS, M.; TANNER, C. B. 1966. Infrared Thermometry of Vegetation. Agron. J., v.58, p.597-601.

GALVÍNCIO， J. $\quad$ D.; DANTAS， L. G.; FERNANDES, J. G.; SILVA, J. B.; MOURA, M. S. B. DE; MACHADO, C. C. C. 2009. Análise da temperatura do ar e da superfície no sítio Boa Felicidade em São José do Sabugi-PB, no semiárido do Brasil. Rev. Geogr., v.26, p.124-141. 
GALVÍNCIO, J. D.; MOURA, M. S. B. DE. 2010. Detecting Hydroclimatic Changes Using SpatioTemporal Analysis in the Sub-Medium São Francisco-PE Basin. J. Environ. Hydrol., v.14, p.114.

GALVÍNCIO, J. D.; PIMENTEL， R. M. M.; FERNANDES, J. G. 2010. Relação da temperatura do ar e do solo com a quantidade de clorofila a e b em Jurema preta (Mimosa tenuiflora (Willd) Poiret) no semi-árido do Nordeste do Brasil. Rev. Bras. Geogr. Fis., v.3, p.41-47.

GLENN, D. M.; SCORZA, R.; BASSETT, C. 2000. Physiological and morphological traits associated with water use efficiency in the willowleaf peach. Hortsci., v.35, p.1241-43.

Godoy O., Lemos-Filho J.P. de, Valladares F., 2011. Invasive species can handle higher leaf temperature under water stress than Mediterranean natives. Environ. Exp. Bot., v.71, p.207-214.

GONÇALVES, P. H. L.; TAVARES, L. P. O.; CHAVES, J. G.; RIBEIRO, J. B. M.; JESUS, E. S.; OLIVEIRA, L. A.; PINHEIRO, F. M. A. 2002. Influência da cobertura plástica na geotemperatura de áreas cultivadas na Amazônia Oriental. In: XII Congresso Brasileiro de Agrometeorologia, Foz do Iguaçu-PR.

GRACE, J. 1977. Plant response to wind. Academic Press, London, New York, San Francisco.

GRIME J. P. 1998. Benefits of plant diversity to ecosystems: immediate, filter and founder effects. J. Ecol., v.86, p.902-910.

HABIT, M. M.; SAAVEDRA, J. C. 1988. The Current State of Knowledge on Prosopis juliflora. Food and Agriculture Organization of the United Nations Plant Production and Protection Division. Disponible:

http://www.fao.org/docrep/006/ad317e/AD317E0 0.htm\#TOC.

HASKELL, D. E.; FLASPOHLER, D. J.; WEBSTER, C. R.; MEYER, M. W. 2012. Variation in Soil Temperature, Moisture, and Plant Growth with the Addition of Downed Woody Material on Lakeshore Restoration Sites. Restor. Ecol., v.20, p.113-121.

HUETE, A. R. 1988. Adjusting vegetation indices for soil influences. Int. Agrophys., v.4, p.367-376.
HUETE, A. R.; WARRICK, A. R. 1990. Assessment of vegetation and soil water regimes in partial canopies with optical remotely sensed data. Remote Sens. Environ., v.32, p.155-167.

IPCC - Intergovernmental Panel on Climate Change. 2007. Fourth Assessment Report Working Group III. Mitigation of Climate Change. Bancoc.

IQBAL, M. 1983. An introduction to Solar Radiation. Academic Press, NY.

JACKSON, R. D.; REGINATO, R. J.; IDSO, S. B. 1977. Wheat canopy temperature - a practical tool for evaluating water requirements. Water Resour. Res., v.13, p.651-656.

JARVIS, P. G.; MCNAUGHTON, S. J. 1986. Stomatal control of transpiration: scaling up from leaf to region. Adv. Ecol. Res., v.15, p.1-49.

JOCHUM, G. M.; MUDGE, K. W.; THOMAS, R. B. 2007. Elevated temperatures increase leaf senescence and root secondary metabolite concentrations in the understory herb Panax quinquefolius (Araliaceae). Am. J. Bot., v.94, p.819-826.

JONES, H. G. 1992. Plants and Microclimate, Cambridge University Press.

JONES, H. G. 1999. Use of thermography for quantitative studies of spatial and temporal variation of stomatal conductance over leaf surfaces. Plant Cell Environ., v.22, p.1043-1055.

JONES, H. G. 2004. Irrigation scheduling: advantages and pitfalls of plant-based methods. J. Exp. Bot., v.55, p.2427-2436.

JONES, H. G.; LEINONEN, I. 2003. Thermal Imaging for the Study of Plant Water Relations. J. Agric. Meteorol., v.53, p.205-217.

JONES, H. G.; STOLL, M.; SANTOS, T.; SOUSA, C.; CHAVES, M. M.; GRANT, O. M. 2002. Use of infrared thermography for monitoring stomatal closure in the field: application to grapevine. J. Exp. Bot., v.53, p.2249-2260.

KLAR, A. E. 1984. Água no sistema solo-plantaatmosfera. "Water in the system soil-plantatmosphere". São Paulo, Nobel.

LARCHER, W. 2003. Physiological Plant Ecology. Ecophysiology and Stress Physiology of Functional Groups. Springer-Verlag. 4rd. 
LEINONEN, I.; GRANT, O. M.; TAGLIAVIA, C. P. P.; CHAVES, M. M.; JONES, H. G. 2006. Estimating stomatal conductance with thermal imagery. Plant Cell Environ., v.29, p.1508-1518.

LEUZINGER, S.; KÖRNER, C. H. 2007. Tree species diversity affects canopy leaf temperatures in a mature temperate forest. Agric. For. Meteorol., v.146, p.29-37.

MAHEY, R. K.; SINGH, R.; SIDHU, S. S.; NARANG, R. S. 1991. The use of remote-sensing to assess the effects of water-stress on wheat. Exp. Agric., v.27, p.423-429.

MARENGO, J. A. 2007. Possíveis impactos da mudança de clima no Nordeste. Revista eletrônica de Jornalismo Científico, v.1-3.

MARKHAM, B. L.; BARKER, L. L. 1987. Thematic mapper bandpass solar exoatmospherical irradiances. Int. J. Remote Sens., v.8, p.517-523.

MATSUSHIMA, D.; KONDO, J. 2000. Estimating regional distribution of sensible heat flux over vegetation using satellite infrared temperature with viewing angle correction. J. Meteor. Soc. Japan., v.78, p.753-763.

MCELWAIN, J. C.; BEERLING, D. J. WOODWARD, F. I. 1999. Fossil plants and global at the Triassic-Jurassic boundary. Science, v.285, p.1386-1390.

MOURA, M. S. B. DE; GALVÍNCIO, J. D.; SILVA, B. B. DA; MACHADO, C. C. C.; SILVA, H. A. DA; OLIVEIRA, T. H. DE. 2012. Gross primary production using related vegetation indices. An Asabe Ann. Int. Meeting, v.7004, p.111.

NEMANI, R. R.; RUNNING, S. W. 1989. Estimation of regional surface-resistance to evapotranspiration from NDVI and thermal-IR AVHRR data. J. Appl. Meteorol., v.28, p.276-284.

PILLAR, V. D. P. 1995. Clima e vegetação. Clima. UFRGS, Departamento de Botânica. (http://ecoqua.ecologia.ufrgs.br/), (accessed 17.02.2016).

PIMENTEL, C.; PEREZ, A. J. C. 2000. Estabelecimento de parâmetros para avaliação de tolerância à seca em genótipos de feijoeiro. Pesq. Agropec. Bras., v.35, p.46-58.
PRADO, D. E. 2003. As Caatingas da América do Sul. In: LEAL, I. R.; TABARELLI, M.; SILVA, J. C. M. DA. (Eds.) Ecologia e conservação da caatinga. Recife: Ed. Universitária da UFPE, pp.373.

RASCHKE, K. 1960. Heat transfer between the plant and the environment. Annu. Rev. Plant Physiol. Plant. Molec. Biol., v.11, p.111-126.

SANTOS, A. M.; GALVÍNCIO, J. D.; MOURA, M. S. B. 2009. Desenvolvimento de Modelo de Balanço Hídrico para a Bacia Hidrográfica do Rio Goiana-PE. In: GALVÍNCIO, J. D.; SILVA, D. F. (Org.). Mudanças climáticas e recursos hídricos: aplicações no estado de Pernambuco. Recife: Ed. Universitária da UFPE. pp.65-78.

SDOODEE, S.; KAEWKONG, P. 2006. Use of an infrared thermometer for assessment of plant water stress in neck orange (Citrus reticulate Blanco). Songklanakarin J. Sci. Technol., v.28, p.11611167.

SILVA, B. B. DA; LOPES, G. M.; AZEVEDO, P. V. DE. 2005. Balanço de radiação em áreas irrigadas utilizando imagens Landsat 5 - TM. Rev. Bras. Meteorol., v.20, p.243-252.

SILVA. B. B.; CÂNDIDO, M. V. 2004. Determinação da evapotranspiração em escala regional através do Sebal e imagens Landsat 5 TM. XIII Congresso Brasileiro de Meteorologia, Fortaleza.

SILVA, L. C.; FIDELES, J. F.; BELTRÃO, N. M.; RAO, T. V. 1998. Variação diurna da resistência estomática à difusão de vapor de água em amendoim irrigado. Pesq. Agropec. Bras., v.33, p.269-76.

SOER, G. J. R. 1980. Estimation of regional evapotranspiration and soil-moisture conditions using remotely sensed crop surface temperature. Rem. Sens. Environ., v.9, p.27-45.

SOUZA, C. R.; SOARES, A. M.; REGINA, M. A. 2001. Troca gasosa de mudas de videira, obtidas por dois porta-enxertos, submetidas à deficiência hídrica. Pesq. Agropec. Bras., v.36, p.1221-30.

TANNER, C. B. 1963. Plant temperatures. Agron. J., v.55, p.210-211.

TURNER, N. C. 1986. Crop Water Deficits: A Decade of Progress. Advances in Agronomy, v.39, p.1-51. 
Journal of Environmental Analysis and Progress V. 01 N. 01 (2016) 1-12

WAGGONER, P. E.; SHAW, R. H. 1952. Temperature of potato and tomato leaves. Pl. Physiol., v.27, p.710-724.

WANJURA, D. F.; UPCHURCH, D. R. 1997. Accounting for humidity in canopy-temperaturecontrolled irrigation scheduling. Agric. Water Manag., v.34, p.217-231.

WIEGAND, C. L.; NAMKEN, L. N. 1966. Influences of plant moisture stress, solar radiation and air temperature on cotton leaf temperature. Agron. J., v.58, p.282-286.

WILSON, D.; COOPER, J. P. 1969. Effect of Temperature during Growth on Leaf Anatomy and Subsequent Light-Saturated Photosynthesis among
Contrasting Lolium Genotypes. New Phytol., v.68, p.1115-1123.

ZAITCHIK, B. F.; MACALADY, A. K.; BONNEAU, L. R.; SMITH, R. B. 2006. Europe's 2003 heat wave: a satellite view of impacts and land-atmosphere feedbacks. Int. J. Climatol., v.26, p.743-769.

ZHANG, R. H.; SUN, X. M.; LIU, J. Y.; SU, H. B.; TANG, X. Z.; ZHU, Z. L. 2003. Determination of regional distribution of crop transpiration and soil water use efficiency using quantitative remote sensing data through inversion. Sci. China Ser. DEarth Sci., v.46, p.10-22. 